\title{
Mechanism of hepatoprotective potential of aqueous leaves extract of Eucalyptus obliqua (Myrtaceae) in carbon tetrachloride intoxicated Wistar rats
}

\author{
Saheed Sabiu ${ }^{\mathrm{a}, \mathrm{b}, c_{*}, \text { Emmanuel Oladipipo Ajani }}{ }^{\mathrm{a}}$, Taofik Olatunde Sunmonu ${ }^{\mathrm{d}}$, Fatai Oladunni Balogun ${ }^{\mathrm{c}}$, \\ Anofi Omotayo Tom Ashafa ${ }^{c}$, Rahmat Bidemi Othman ${ }^{\text {a }}$, Sunday Kehinde Olowa ${ }^{a}$ \\ ${ }^{a}$ Phytomedicine, Food factors and Toxicology Research Laboratory, Biochemistry Department, School of Basic Medical Sciences, Kwara State University, \\ Malete. P.M.B. 1530, Ilorin, Nigeria. ${ }^{b}$ Department of Microbial, Biochemical, and Food Biotechnology, University of the Free State, Bloemfontein, South \\ Africa. ${ }^{~}$ Phytomedicine and Phytopharmacology Research Group, Plant Sciences Department, University of the Free State, Qwaqwa campus, South Africa. \\ ${ }^{\mathrm{d}}$ Phytomedicine and Plant Biochemistry Research Laboratory, Biochemistry Unit, Department of Biological Sciences, Al-Hikmah University, Ilorin, \\ Nigeria.
}

\section{ARTICLE INFO}

\section{Article history:}

Received on: 04/02/2017

Accepted on: 27/04/2017

Available online: 30/08/2017

\section{Key words:}

Antioxidant enzyme, Carbon tetrachloride, Eucalyptol, Hepatic injury, Oxidative stress.

\begin{abstract}
This study investigated the protective mechanism of aqueous leaves extract of Eucalyptus obliqua (EOAE) in $\mathrm{CCl}_{4}$-mediated liver damage in Wistar rats. The animals were orally pretreated with either the extract (200 and $400 \mathrm{mg} / \mathrm{kg})$ or vitamin $\mathrm{C}(200 \mathrm{mg} / \mathrm{kg})$ for 10 days prior to the intraperitoneal administration of $3 \mathrm{~mL} / \mathrm{kg}$ $\mathrm{CCl}_{4}$ (30\% in olive oil). Subsequently, hepatic function, antioxidant and histological analyses were evaluated. The results showed that the $\mathrm{CCl}_{4}$-induced increases in the activities of ALT, ALP, AST and the concentrations of bilirubin, oxidized glutathione and malondialdehyde were significantly and dose-dependently reduced in the extract-treated rats. The extract also significantly improved the attenuated activities of superoxide dismutase, catalase, glutathione reductase and glutathione peroxidase as well as total protein, albumin and glutathione concentrations in the hepatotoxic animals. These improvements could be attributed to the phytoconstituents revealed by the GCMS analysis of the extract. The observed activities compared with that of vitamin $\mathrm{C}$ and are suggestive of hepatoprotective and antioxidant properties of EOAE and were also supported by the histological results. Overall, these data indicate that EOAE has a significant protective effect against acute $\mathrm{CCl}_{4}$-induced hepatotoxicity in rats, which may be due to its capability to fortify the antioxidant defense systems.
\end{abstract}

\section{INTRODUCTION}

Carbon tetrachloride $\left(\mathrm{CCl}_{4}\right)$ is an experimentally established agent to induce hepatic damage in animals (Adekeye et al., 2014; Balogun and Ashafa, 2016). $\mathrm{CCl}_{4}$-mediated hepatotoxicity is caused primarily through oxidative stress resulting from free radicals chain events. The free radicals and other reactive metabolites formed subsequent to $\mathrm{CCl}_{4}$ administration results in impaired endoplasmic reticulum and altered permeability of the mitochondrial membrane of the hepatocytes. This consequently facilitates accumulation of lipids,

Corresponding Author

Email: saeed.sabiu@gmail.com reduction of protein synthesis and oxidative stress-perturbed hepatocellular necrosis (Weber et al., 2003). While the effectiveness of conventional treatment options (life style changes, medications, and surgery) for hepatic disorders are guaranteed, affordability, non-compliance, limited efficacy and potentially lifethreatening side effects have undermined their uses (Ward and Daly, 1999). However, botanicals with significant hepatoprotective potentials are readily available, more affordable, easily accessible and often with minimal side effects and are being explored globally as alternative therapy (Mahmud et al., 2012; Sabiu et al., 2016). The continuous search for hepatoprotective phytoagents might be due in part, to their excellently displayed antioxidant properties in preventing undesirable auto oxidation either by halting harmful influence of reactive metabolites or simply as 
reactive oxygen species scavengers. Interestingly, Eucalyptus obliqua is one of the plants that have been advocated in the management of liver ailments.

Eucalyptus obliqua L.Her. (Myrtaceae) Blakely is an evergreen tree of the Australian origin with characteristic fast growing features. It is an exclusive specie of the eucalyptus family where other species derived their common trait of having oblique leaves. Besides being ornamental, E. obliqua is used to drain swamps and also very effective as an antimalarial (Barry et al., 2015). In the traditional systems of medicine, leaf infusions of $E$. obliqua are highly ethnomedicinally valued in the treatment of malaria fever, inflammation, diabetes mellitus and liver disorders (Barry et al., 2015; Sabiu and Ashafa, 2016). Additionally, results of our ethnopharmacological survey of medicinal plants of the Local Government Areas of Kwara State, Nigeria, also presented E. obliqua as a botanical that is used to manage and treat liver ailments. In view of this and coupled with no previous scientific reports on its potential to treat hepatic diseases, the present study investigated the probable mechanism of the hepatoprotective effect of its aqueous leaves extract in $\mathrm{CCl}_{4}$-perturbed hepatotoxicity in Wistar rat model. The GC-MS analysis of the extract was also performed.

\section{MATERIALS AND METHODS}

\section{Chemicals, reagents and assay kits}

All the chemicals, reagents and assay kits used were of analytical grade.

\section{Plant collection, authentication and extract preparation}

Fresh leaves of Eucalyptuc obliqua (EO) were collected from the Kwara State Ministry of Agriculture, Ilorin, Nigeria, in the month of April, 2014. Taxonomical authentication was done by Mr. Bolu (Chief Taxonomist) of the Department of Plant Biology, University of Ilorin, Ilorin, Nigeria and a voucher specimen (Reference no. UIH001/1178) was deposited in the Departmental herbarium. The leaves of EO were carefully rinsed under running water tap to remove foliar contaminants prior to airdrying to constant weight. Subsequently, the leaves were pulverized into coarse powder using an electric blender (model MS-223; Blender/Miller III, Taiwan, China). A portion (300 g) of the powdered sample was exhaustively extracted with continuous agitation in distilled water. The resulting infusion was filtered (Whatman no. 1 filter paper) and lyophilized using Virtis Bench Top lyophilizer (SP Scientific Series, USA). This yielded $37.8 \mathrm{~g}$ crude extract (EOAE) corresponding to $12.6 \%$ of the powdered sample.

\section{Experimental animals}

Subsequent to Departmental Ethical clearance (KSU/IECCULA/003/02/016) for the study, a total of thirty male Wistar rats (mean weight: $120 \pm 5.2 \mathrm{~g}$ ) were collected from the Animal Facility of the Biochemistry Laboratory, Kwara State University, Malete, Nigeria. The rats were housed in clean metallic cages, maintained under standard laboratory conditions and had ad libitum access to standard pellets and potable water. They were allowed ten days of acclimatization before being used for experimentation and the whole treatment was in accordance with the guidelines of National Research Council Guide for the Care and Use of Laboratory Animals (NRC, 2011).

\section{Experimental protocol \\ Induction of hepatotoxicity}

Adopting the modified method of Lu et al. (2002) using $30 \%$ carbon tetrachloride dissolved in olive oil, hepatic damage was induced in rats. Briefly, the animals were intraperitoneally administered with a single dose $(3 \mathrm{~mL} / \mathrm{kg})$ of the $30 \% \mathrm{CCl}_{4}$ solution.

\section{Animal grouping and treatments}

The animals were randomized into 6 groups of 5 rats for this experiment. Rats in group 1 were given sterile placebo (distilled water) and designated as control. Group 2 comprised animals (hepatotoxic control) induced with hepatotoxicity but not treated. Animals in group 3 received $400 \mathrm{mg} / \mathrm{kg}$ b.w. of EOAE only, while rats in groups 4,5 and 6 were hepatotoxic rats pretreated with EOAE (200 and $400 \mathrm{mg} / \mathrm{kg}$ b.w.) and vitamin C (200 $\mathrm{mg} / \mathrm{kg}$ b.w.) respectively. Pre-treatments with the standard drug and extract were done once daily via oral intubation and lasted for 10 days prior to hepatotoxicity induction. A transition period of 24 $\mathrm{h}$ was observed after the last oral pre-treatment with the graded doses of EOAE and vitamin $\mathrm{C}$ before $\mathrm{CCl}_{4}$ administration. Prior to the termination of the studies, the rats were fasted over night but had ad libitum access to water.

\section{Serum preparation and excision of liver}

Forty eight hours after $\mathrm{CCl}_{4}$ treatment, the rats were humanely sacrificed by halothane anaesthetization and blood was collected by cardiac puncture into non-heparinized tubes. Serum was subsequently prepared, carefully aspirated and used for liver function tests. The rats were also quickly dissected and the liver isolated, blotted with clean tissue paper, cleaned of fat and sliced into two portions. A portion was homogenized in ice-cold Tris$\mathrm{HCl}$ buffer $(0.05 \mathrm{~mol} / \mathrm{L}$ Tris- $\mathrm{HCl}$ and $1.15 \% \mathrm{KCl}, \mathrm{pH} 7.4)$ for antioxidant analyses, while the other portion was used for histological examination.

\section{Liver function indices and antioxidant analyses}

Liver function parameters were evaluated according to manufacturer's instructions on the assay kits. Serum activities of aspartate aminotransferase (AST), alanine aminotransferase (ALT), alkaline phosphatase (ALP) as well as albumin, bilirubin and protein concentrations were assayed. While the homogenate activities of glutathione peroxidase (GPx), superoxide dismutase (SOD), catalase (CAT) and glutathione reductase (GRx) were assayed using the methods of Rotruck et al. (1973), Marklund and Marklund (1974), Aebi (1984), and Thabrew et al. (1987) 
respectively, level of malondialdehyde (MDA) was evaluated adopting the methods of Reilly and Aust (2001). The reported protocols of Ellman (1959) and Hissin and Hilf (1976) were employed in the determination of reduced glutathione (GSH) and oxidized glutathione (GSSG) concentrations, respectively.

\section{Histopathological examination}

The reported method of Drury and Wallington (1980) was adapted for the histopathological examination of the harvested liver sections. Microscopic features of the hepatocytes of EOAE and vitamin $\mathrm{C}$-treated rats were compared with both normal and hepatotoxic control groups. Based on the degree of hepatic damage observed, the liver sections were further evaluated and scored by the histopathologist who was unaware of the experimental treatments. Scores were assigned on a 0 to 4 scale as earlier reported (Sabiu et al., 2016).

\section{GCMS analysis of the extract}

Using an Agilent Technologies 6890 Series gas chromatograph coupled with an Agilent 5973 Mass Selective detector driven by Agilent Chemstation software, the GC-MS analysis of EOAE was performed. The operating conditions included: An eHP-5MS capillary column $(30 \mathrm{~m} \times 0.25 \mathrm{~mm}$ internal diameter, $0.25 \mu \mathrm{m}$ film thickness), ultra-pure helium (carrier gas) at a flow rate of $1.0 \mathrm{~mL} / \mathrm{min}$ and a linear velocity of $37 \mathrm{~cm} / \mathrm{s}$, injector temperature $\left(300^{\circ} \mathrm{C}\right)$, initial oven temperature $\left(10^{\circ} \mathrm{C}\right.$ with flexibility of lower sensitivity) programmed to increase to $300^{\circ} \mathrm{C}$ at the rate of $10^{\circ} \mathrm{C} / \mathrm{min}$ with a hold time of $4 \mathrm{~min}$ at each increment and the extract $(2 \mu \mathrm{L})$ was injected in the splitless mode with a split ratio of 20:1. The mass spectrometer (MS) was operated in the electron ionization mode $(70 \mathrm{eV})$ and electron multiplier voltage $(1859 \mathrm{~V})$. Other operating parameters for the MS were as follows: ion source temperature $230^{\circ} \mathrm{C}$, quadruple temperature $150^{\circ} \mathrm{C}$, solvent delay $4 \mathrm{~min}$ and scan range 50-700 amu. For the identification of the constituents of EOAE, direct comparison of the retention times, mass spectral data and fragmentation pattern of the compounds were made with those in the National Institute of Standards and Technology (NIST) library and Wiley libraries having more than 75,000 compounds. The name, structure, molecular weight and \%composition of each constituent having super impossible factor value of greater than 90 was subsequently ascertained.

\section{Data analysis}

Results were subjected to one-way analysis of variance (ANOVA) using SPSS 16.0 (SPSS Inc., South Wacker Drive, Chicago, USA) and expressed as mean \pm standard error of mean $(\mathrm{SEM})(\mathrm{n}=5)$. Significant difference between the treatments mean were determined at $\mathrm{p}<0.05, \mathrm{p}<0.001$ and $\mathrm{p}<0.0001$ confidence levels using Duncan's Multiple Range Test.

\section{RESULTS}

The results of EOAE pre-treatments on the liver function indices of the animals are shown in Tables 1 and 2 . While intraperitoneal injection of $\mathrm{CCl}_{4}(3 \mathrm{~mL} / \mathrm{kg})$ caused significant $(\mathrm{p}<$ 0.05 ) elevation in the specific activities of AST, ALT, ALP and concentration of bilirubin, the levels of albumin and total protein were significantly reduced $(\mathrm{p}<0.05)$ when compared with the normal control. However, the observed alterations in these liver function indices were significantly $(\mathrm{p}<0.05)$ and dosedependently reversed in the extract pre-treated rats. It is also noteworthy that the most prominent effect that compared well with the vitamin $\mathrm{C}$ treated animals were observed at the highest investigated dose (400 mg/kg b.w.) of EOAE (Tables 1 and 2). The rats placed on $400 \mathrm{mg} / \mathrm{kg}$ dose of the extract alone showed no traces of hepatotoxic tendencies as they compared well with the normal control for these parameters.

Table 1: Effect of Eucalyptus obliqua aqueous leaf extract on serum activities of liver function enzymes of $\mathrm{CCl}_{4}$-treated rats.

\begin{tabular}{|c|c|c|c|}
\hline Treatments & $\operatorname{ALP}(\mathbf{U} / \mathbf{I})$ & ALT (U/I) & AST (U/I) \\
\hline Sterile placebo (Control) & $175.09 \pm 1.32^{\mathrm{a}}$ & $23.15 \pm 0.03^{\mathrm{a}}$ & $30.89 \pm 0.05^{\mathrm{a}}$ \\
\hline $\mathrm{CCl}_{4}$ treated & $333.21 \pm 1.08^{\mathrm{b}}$ & $70.99 \pm 0.05^{\mathrm{b}}$ & $100.76 \pm 0.05^{\mathrm{b}}$ \\
\hline $400 \mathrm{mg} / \mathrm{kg}$ b.w. EOAE & $173.45 \pm 1.35^{\mathrm{a}}$ & $22.87 \pm 0.05^{\mathrm{a}}$ & $29.99 \pm 0.03^{\mathrm{a}}$ \\
\hline $200 \mathrm{mg} / \mathrm{kg}$ b.w. EOAE $+\mathrm{CCl}_{4}$ & $222.21 \pm 1.75^{\mathrm{c}}$ & $45.12 \pm 0.03^{\mathrm{c}}$ & $50.89 \pm 0.03^{\mathrm{c}}$ \\
\hline $400 \mathrm{mg} / \mathrm{kg}$ b.w. EOAE+ $\mathrm{CCl}_{4}$ & $174.21 \pm 1.45^{\mathrm{a}}$ & $22.99 \pm 0.04^{\mathrm{a}}$ & $32.09 \pm 0.01^{\mathrm{a}}$ \\
\hline $200 \mathrm{mg} / \mathrm{kg}$ b.w. vitamin $\mathrm{C}+\mathrm{CCl}_{4}$ & $173.92 \pm 1.09^{\mathrm{a}}$ & $31.09 \pm 0.03^{\mathrm{d}}$ & $33.33 \pm 0.08^{\mathrm{a}}$ \\
\hline
\end{tabular}

Table 2: Effect of Eucalyptus obliqua aqueous leaf extract on serum levels of albumin, bilirubin and total protein of $\mathrm{CCl}_{4}$-treated rats

\begin{tabular}{|c|c|c|c|}
\hline Treatments & $\operatorname{Albumin}(\mathrm{g} / \mathrm{L})$ & Bilirubin $(\mu \mathrm{mol} / \mathrm{l})$ & Protein $(\mathrm{g} / \mathrm{L})$ \\
\hline Sterile placebo (Control) & $5.95 \pm 0.05^{\mathrm{a}}$ & $12.01 \pm 0.05^{\mathrm{a}}$ & $35.88 \pm 0.05^{\mathrm{a}}$ \\
\hline $\mathrm{CCl}_{4}$ treated & $0.23 \pm 0.03^{\mathrm{b}}$ & $53.99 \pm 0.04^{b}$ & $13.24 \pm 0.01^{\mathrm{b}}$ \\
\hline 400 mg/kg b.w. EOAE & $5.81 \pm 0.02^{\mathrm{a}}$ & $19.25 \pm 0.09^{c}$ & $34.55 \pm 0.05^{\mathrm{a}}$ \\
\hline $200 \mathrm{mg} / \mathrm{kg}$ b.w. EOAE+ $\mathrm{CCl}_{4}$ & $2.24 \pm 0.02^{\mathrm{c}}$ & $33.73 \pm 0.05^{\mathrm{d}}$ & $25.17 \pm 0.04^{\mathrm{c}}$ \\
\hline $400 \mathrm{mg} / \mathrm{kg}$ b.w. $\mathrm{EOAE}+\mathrm{CCl}_{4}$ & $6.01 \pm 0.06^{\mathrm{a}}$ & $11.57 \pm 0.25^{\mathrm{a}}$ & $33.24 \pm 0.04^{\mathrm{a}}$ \\
\hline $200 \mathrm{mg} / \mathrm{kg}$ b.w. vitamin $\mathrm{C}+\mathrm{CCl}_{4}$ & $5.89 \pm 0.10^{\mathrm{a}}$ & $11.60 \pm 0.25^{\mathrm{a}}$ & $33.56 \pm 0.01^{\mathrm{a}}$ \\
\hline
\end{tabular}


Tables 3 and 4 show the effects of oral pre-treatments with EOAE and subsequent intraperitoneal $\mathrm{CCl}_{4}$ treatment on the antioxidant biomarkers (SOD, CAT, GPx, GRx, GSH and GSSG) and MDA in the treated rats. $\mathrm{CCl}_{4}$ treatment caused significant ( $\mathrm{p}$ $<0.05$ ) decreases in the hepatic tissue SOD, CAT, GPx, GRx, and GSH while causing significant $(\mathrm{p}<0.05)$ increases in the GSSG and MDA. Oral pre-treatment with 200 and $400 \mathrm{mg} / \mathrm{kg}$ b.w. doses of EOAE significantly $(\mathrm{p}<0.05)$ induced the hepatic activities of SOD, CAT, GPx, and GRx as well improved the GSH level in a dose-related manner.

The levels of GSSG and MDA were also significantly attenuated in the extract treated animals. These effects (particularly at $400 \mathrm{mg} / \mathrm{kg}$ b.w. of the extract) competed favourably with that of the vitamin $\mathrm{C}$ administered rats. The antioxidant status of the animals given $400 \mathrm{mg} / \mathrm{kg}$ b.w. of EOAE alone was also significantly $(\mathrm{p}<0.05)$ boosted. Macroscopic examination of the liver sections from normal control group revealed that they were normal with characteristic dark maroon colour and smooth texture. While the liver from the $\mathrm{CCl}_{4}$-intoxicated rats showed changes in colour from maroon to brown with characteristic uneven texture, those of the extract-treated animals revealed mild spots of brown colour changes. Furthermore, detailed histoarchitectural examination of the liver of the control rats showed normal morphological features with wellpreserved cords of hepatocytes, well demarcated sinusoids and no area of infiltration by inflammatory cells (Figure 1a). This is in contrast to the hepatic centrilobular vacuolation and vascular congestion indicative of early hepatic necrosis observed in the untreated $\mathrm{CCl}_{4}$ injected animals (Fig. 1b). However, oral pretreatments with vitamin $\mathrm{C}$ and the extract for 10 days revealed significantly preserved and attenuated $\mathrm{CCl}_{4}$-induced histological lesions of hepatic necrosis (Figs. 1c-f). Furthermore, the histopathological grading of the liver tissues of the extractadministered groups showed that the obvious necrosis, inflammation, and haemorrhage present in the hepatocytes of the $\mathrm{CCl}_{4}$-intoxicated rats were significantly and dose-dependently prevented in a manner comparable to the vitamin $\mathrm{C}$ administered animals (Table 5). Results from the GC-MS analysis of the extract revealed the presence of eucalyptol, ursolic acid, thymol, 3-hexen1-ol, triterpenoic acid, isopinocarveol, 1,8-cineole, $\alpha$-pinene, quercetin and procyanidins as major identifiable adaptogenic constituents (Table 6).

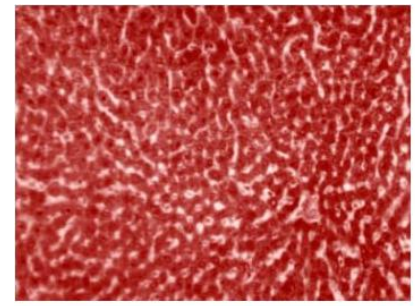

(a)

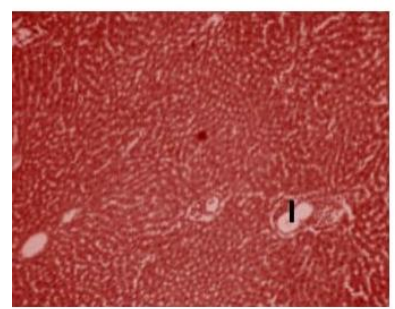

(d)

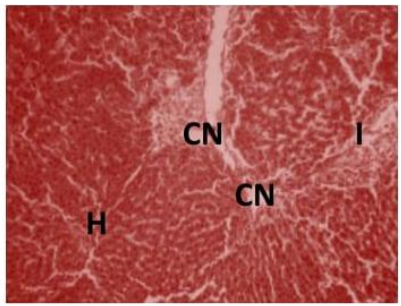

(b)

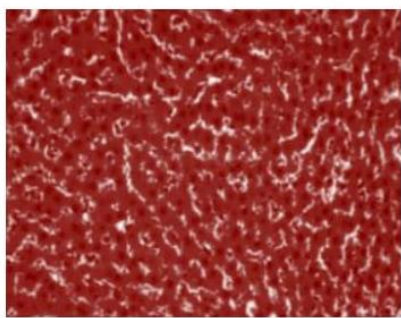

(e)

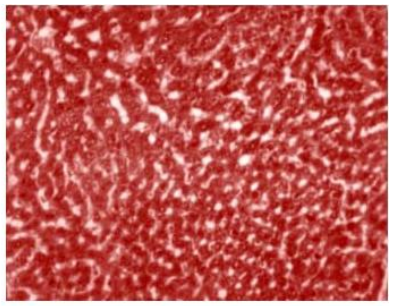

(c)

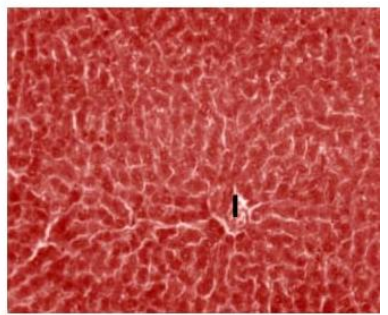

(f)

Fig. 1: Liver micrograghs (x 400, Haematoxylin and eosin stained) of (a) Normal control rat, (b) Hepatotoxic rat, (c) EOAE (400 mg/kg b.w) treated rat, (d) Hepatotoxic rat pre-treated with EOAE (200 mg/kg b.w), (e) Hepatotoxic rat pre-treated with EOAE ( $400 \mathrm{mg} / \mathrm{kg}$ b.w), (f) Hepatotoxic rat pre-treated with vitamin $\mathrm{C}(200 \mathrm{mg} / \mathrm{kg}$ b.w $)$. EOAE= E. obliqua aqueous extract, $\mathrm{I}=$ inflammation, $\mathrm{CN}=$ coagulative necrosis, $\mathrm{H}=$ haemorrhage

Table 3: Effect of Eucalyptus obliqua aqueous leaf extract on specific activities of enzymic antioxidant system of $\mathrm{CCl}_{4}$-treated rats.

\begin{tabular}{|c|c|c|c|c|}
\hline \multirow[b]{2}{*}{ Treatments } & \multicolumn{4}{|c|}{ Antioxidant enzymes (nmol min- ${ }^{1}$ mgprotein- $\left.^{1}\right)$} \\
\hline & SOD & Catalase & Glutathione Rx & Glutathione Px \\
\hline Sterile placebo (Control) & $55.03 \pm 1.25^{\mathrm{a}}$ & $44.11 \pm 1.05^{\mathrm{a}}$ & $68.01 \pm 1.25^{\mathrm{a}}$ & $249.99 \pm 1.45^{\mathrm{a}}$ \\
\hline $\mathrm{CCl}_{4}$ treated & $23.09 \pm 1.30^{\mathrm{b}}$ & $13.99 \pm 1.11^{\mathrm{b}}$ & $27.09 \pm 1.30^{\mathrm{b}}$ & $100.01 \pm 1.09^{b}$ \\
\hline $400 \mathrm{mg} / \mathrm{kg}$ b.w. EOAE & $70.09 \pm 1.21^{\mathrm{c}}$ & $59.99 \pm 1.09^{c}$ & $70.44 \pm 1.23^{\mathrm{a}}$ & $269.45 \pm 1.12^{\mathrm{c}}$ \\
\hline $200 \mathrm{mg} / \mathrm{kg}$ b.w. EOAE $+\mathrm{CCl}_{4}$ & $45.23 \pm 1.09^{\mathrm{d}}$ & $32.98 \pm 1.05^{\mathrm{d}}$ & $43.01 \pm 1.44^{\mathrm{c}}$ & $210.99 \pm 1.10^{\mathrm{d}}$ \\
\hline $400 \mathrm{mg} / \mathrm{kg}$ b.w. EOAE+ $\mathrm{CCl}_{4}$ & $53.67 \pm 1.23^{\mathrm{a}}$ & $43.56 \pm 1.22^{\mathrm{a}}$ & $69.45 \pm 1.23^{\mathrm{a}}$ & $247.99 \pm 1.09^{\mathrm{a}}$ \\
\hline $200 \mathrm{mg} / \mathrm{kg}$ b.w. vitamin $\mathrm{C}+\mathrm{CCl}_{4}$ & $52.01 \pm 1.25^{\mathrm{a}}$ & $42.99 \pm 1.26^{\mathrm{a}}$ & $68.89 \pm 1.45^{\mathrm{a}}$ & $236.19 \pm 1.99^{\mathrm{e}}$ \\
\hline
\end{tabular}

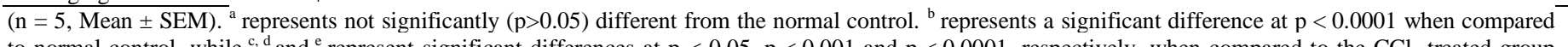

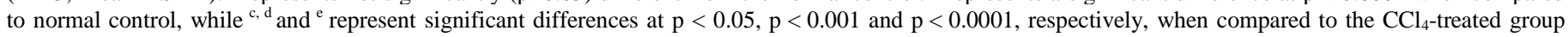
alone. $\mathrm{EOAE}=$ Eucalyptus obliqua aqueous extract, $\mathrm{SOD}=$ superoxide dismutase, $\mathrm{Rx}=$ reductase, $\mathrm{Px}=$ peroxidase. 
Table 4: Effect of Eucalyptus obliqua aqueous leaf extract on the levels of non-enzymic antioxidant system and $\mathrm{MDA}_{\text {of }} \mathrm{CCl} \mathrm{H}_{4}$-treated rats.

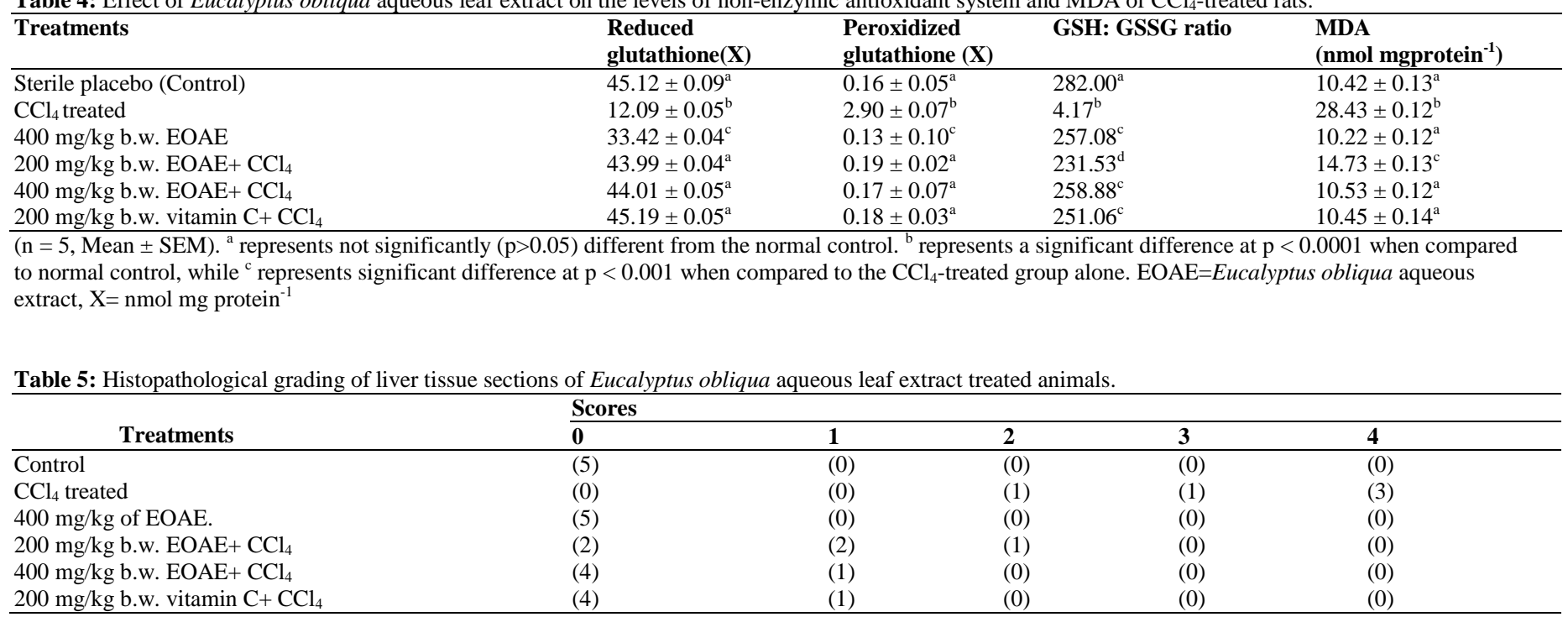

$(\mathrm{n}=5$; figure in parenthesis represents number of rats affected in the group). EOAE=Eucalyptus obliqua aqueous extract

Table 6: Bioactive constituents of E. obliqua aqueous leaf extract as revealed by GC-MS chromatogram.

\begin{tabular}{|c|c|c|c|c|c|}
\hline Peak & Constituent & RT (Min) & Area \% & MF & MW (g/mol) \\
\hline 1 & Drimenol & 2.63 & 6.97 & $\mathrm{C}_{15} \mathrm{H}_{26} \mathrm{O}$ & 222.37 \\
\hline 2 & Eucalyptol $^{\#}$ & 3.53 & 1.25 & $\mathrm{C}_{10}^{15} \mathrm{H}_{10}^{26} \mathrm{O}$ & 154.25 \\
\hline 3 & Ursolic acid ${ }^{\#}$ & 4.20 & 1.49 & $\mathrm{C}_{30} \mathrm{H}_{48} \mathrm{O}_{3}$ & 456.70 \\
\hline 4 & Lactone acetate & 4.68 & 2.40 & $\mathrm{C}_{24} \mathrm{H}_{36} \mathrm{O}_{4}$ & 59.04 \\
\hline 5 & Thymol $^{\#}$ & 5.13 & 1.25 & $\mathrm{C}_{10} \mathrm{H}_{14} \mathrm{O}$ & 150.22 \\
\hline 6 & Cis-nerolidol* ${ }^{*}$ & 5.38 & 2.52 & $\mathrm{C}_{15} \mathrm{H}_{26} \mathrm{O}$ & 222.37 \\
\hline 7 & Cis-geranoil* & 6.05 & 4.82 & $\mathrm{C}_{10} \mathrm{H}_{18}^{20} \mathrm{O}$ & 154.25 \\
\hline 8 & 3-hexen-1-ol & 6.58 & 6.40 & $\mathrm{C}_{6} \mathrm{H}_{12} \mathrm{O}$ & 100.16 \\
\hline 9 & Eucalyptanoic acid* & 7.05 & 2.94 & $\mathrm{C}_{30} \mathrm{H}_{46} \mathrm{O}_{3}$ & 354.31 \\
\hline 10 & Triterpenoic acid & 7.30 & 4.95 & $\mathrm{C}_{30} \mathrm{H}_{48}$ & 456.71 \\
\hline 11 & Spathunelol & 7.57 & 1.80 & $\mathrm{C}_{15} \mathrm{H}_{24} \mathrm{O}$ & 220.35 \\
\hline 12 & Isopinocarveol* & 7.77 & 5.35 & $\mathrm{C}_{10} \mathrm{H}_{18}^{24} \mathrm{O}$ & 154.25 \\
\hline 13 & $\alpha$-pinene ${ }^{\#}$ & 8.42 & 8.15 & $\mathrm{C} \mathrm{H}_{10}$ & 136.24 \\
\hline 14 & $1,8-$ cineol $^{\#} \mathrm{e}$ & 9.13 & 5.99 & $\mathrm{C}_{10} \mathrm{H}_{18} \mathrm{O}$ & 154.25 \\
\hline 15 & P-cymene* & 9.42 & 2.34 & $\mathrm{C}_{10} \mathrm{H}_{14}$ & 134.21 \\
\hline 16 & Linalool* & 9.73 & 3.99 & $\mathrm{C}_{10} \mathrm{H}_{18} \mathrm{O}$ & 154.25 \\
\hline 17 & $\gamma$-terpinene* & 10.13 & 4.77 & $\mathrm{C}_{10} \mathrm{H}_{16}$ & 136.23 \\
\hline 18 & Quercetin $^{\#}$ & 10.85 & 7.01 & $\mathrm{C}_{15} \mathrm{H}_{10} \mathrm{O}_{7}$ & 302.24 \\
\hline 19 & $\alpha$-terpineol ${ }^{\#}$ & 11.10 & 2.55 & $\mathrm{C}_{10} \mathrm{H}_{18} \mathrm{O}$ & 154.25 \\
\hline 20 & Terpinen-4- ol* & 11.38 & 3.10 & $\mathrm{C}_{10} \mathrm{H} \underset{18}{\mathrm{O}} \mathrm{O}$ & 154.25 \\
\hline 21 & Euglobals* & 12.05 & 5.46 & $\mathrm{C}_{23} \mathrm{H}_{30} \mathrm{O}_{5}$ & 386.48 \\
\hline 22 & Aromadendrene* & 12.66 & 7.60 & $\mathrm{C}_{15} \mathrm{H}_{24}$ & 204.35 \\
\hline 23 & Bicyclogermacrene* & 13.25 & 2.43 & $\mathrm{C}_{15} \mathrm{H}_{24}$ & 204.35 \\
\hline 24 & $\beta$-phellandrene* & 13.98 & 3.06 & $\mathrm{C}_{10} \mathrm{H}_{16}$ & 136.24 \\
\hline 25 & $\beta$-bisabolene* & 14.93 & 1.05 & $\mathrm{C}_{15} \mathrm{H}_{24}$ & 204.36 \\
\hline 26 & Procyanidins $^{\#}$ & 15.42 & 0.34 & $\mathrm{C}_{30} \mathrm{H}_{26} \mathrm{O}_{12}$ & 578.52 \\
\hline
\end{tabular}

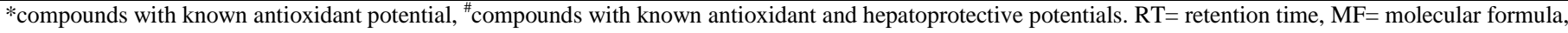
$\mathrm{MW}=$ Molecular weight.

\section{DISCUSSION}

The liver is naturally endowed with the major task of drug detoxification and excretion. Many toxicants have been studied and established to induce varying degrees of hepatic injury (Sabiu et al., 2016). One of such potent hepatotoxicant is the $\mathrm{CCl}_{4}$. The $\mathrm{CCl}_{4}$-induced hepatic injury is a classical and reliable model 
of xenobiotic-induced hepatotoxicity that has been well studied and adopted to screen drugs for their possible hepatoprotective potential (Balogun and Ashafa, 2016). It is metabolically activated by the hepatic CYP2E1 to form $\mathrm{CCl}_{3}{ }^{*}$ radical, which spontaneously reacts with molecular oxygen, forming trichloromethyl peroxy radical $\left(\mathrm{CCl}_{3} \mathrm{OO}^{*}\right)$, that subsequently interacts with important macromolecules (lipids, proteins and DNA) to induce auto-oxidation (Risal et al., 2012). This results in ROS formation that promotes functional loss of membranal integrity, alters enzyme activities, and consequently results in hepatic injury or necrosis (Rajib et al., 2009). When these happen, cytosolic AST, ALT and ALP are released into systemic circulation and their measurement can be used to assess the extent of drug-induced hepatotoxicity (Jaeschke et al., 2003). In this study, the elevated activities of these marker enzymes in the $\mathrm{CCl}_{4}$-intoxicated rats may be indicative of liver damage and cell necrosis resulting from formation of $\mathrm{CCl}_{3}{ }^{*}$ in excess of GSH detoxification capacity. This is in agreement with previous studies (Surendra et al., 2012; Balogun and Ashafa, 2016), where $\mathrm{CCl}_{4}$ administration proved toxic to hepatocytes. However, the significantly and dose-dependently reduced specific activity of these enzymes in rats treated with EOAE suggests that it was able to prevent the harmful effects of $\mathrm{CCl}_{4}$. This observation indicates hepatoprotective potential of the EOAE at the tested doses.

While the biological value of bilirubin has been employed to assess the excretory role of the liver (Tietz, 1995), the metabolic alterations in the serum concentrations of albumin and total protein are used to monitor its secretory capability (Oloyede and Sunmonu, 2009). In the present study, the significantly increased serum level of bilirubin in the untreated hepatotoxic rats could be associated with $\mathrm{CCl}_{4}$-mediated defect in the carriermediated saturable system at the sinusoidal surface of the hepatocytes that consequently obstruct bilirubin uptake and secretion into bile (Sabiu et al., 2014). Similarly, the $\mathrm{CCl}_{4^{-}}$ mediated significant reduction in the levels of albumin and total protein may be suggestive of diminished synthetic function of the liver (Sabiu et al., 2015). Conversely, the dose-dependent and significant improvements in albumin and total protein levels coupled with the reduced concentration of bilirubin in the extracttreated rats is indicative of aided secretory and excretory functions of the hepatocytes facilitated by the EOAE. This does not only suggest that the extract is endowed with phytonutrients capable of stabilizing the plasma membrane of the hepatocytes but also supportive of its hepatoprotective attribute. This assertion agrees with previous submissions (Guo-Cai et al., 2012; Selvaraj et al., 2016), where normalization of the hepatic protein systems in $\mathrm{CCl}_{4}$ intoxicated rats was attributed to the bioactive constituents of plant extracts.

The role of oxidative stress in the pathogenesis of hepatic disorders is well documented (Cesaratto et al., 2004; Sabiu et al., 2016). The free radicals generated as a result of reductive halogenation of $\mathrm{CCl}_{4}$, in the presence of oxygen, bind covalently to membrane macromolecules and abstract hydrogen atoms. This consequently initiates auto-oxidative chain reactions that cause functional and morphological alterations in the hepatocyte cell membrane (Basu, 2003). Hence, prevention and/or inhibition of free radical generation and augmentation of the body's antioxidant defense system are germane to annihilating deleterious influence of $\mathrm{CCl}_{4}$-induced hepatic injury (Wang et al., 2005). The decreased tissue activities of the assayed antioxidant enzymes (SOD, CAT, GRx and GPx) could be due to their excessive mobilization towards detoxification of $\mathrm{CCl}_{3} *$ and free radicals during $\mathrm{CCl}_{4}$ hepatotoxicity. This might have led to uncontrolled oxidative attack on cellular macromolecules that consequently results in necrosis (Sabiu et al., 2014). This finding is consistent with the report of Lu et al. (2002) where similar reductions in activities of radicals detoxifying enzymes were associated with formation of $\mathrm{CCl}_{3} *$ and free radicals in $\mathrm{CCl}_{4}$-mediated hepatotoxicity in rats. Thus, the dose-dependent significant reversion of the $\mathrm{CCl}_{4}$ induced reduction in the activities of these detoxifying enzymes by EOAE is informative of its antioxidant potential. This may be adduced to the tendency of the extract to either scavenge $\mathrm{CCl}_{3}$ * and other free radicals or induce and optimize radicals detoxifying enzymes. Similarly, the observed attenuation in the level of GSH might be due to depletion of GPx and GR, as well as formation of reactive metabolites in excess of GSH detoxification capacity (Gini and Muraleedhara, 2010).

In addition, $\mathrm{CCl}_{4}$-mediated elevation in the level of GSSG may be ascribed to either GSH auto-oxidation or its mobilization towards formation of GPx. The reduction in the GSH/GSSG ratio caused by $\mathrm{CCl}_{4}$ intoxication reveals possible oxidative onslaught on the hepatocytes. However, the significantly and dose-dependently improved GSH level coupled with the corresponding high GSH/GSSG ratio and low GSSG levels in the liver of the extract-treated rats relative to the untreated $\mathrm{CCl}_{4}$ intoxicated rats is suggestive of the probable antioxidant activity of EOAE and further supports that it offered considerable level of hepatoprotection at the investigated doses. This was also evidently supported by the optimized antioxidant status of the rats placed on $400 \mathrm{mg} / \mathrm{kg}$ b.w. of EOAE alone. Furthermore, $\mathrm{CCl}_{4}$ has been linked with lipid peroxidation and may facilitate elevated level of peroxidized products like MDA in hepatotoxicity (Balogun and Ashafa, 2016). Therefore, the significantly increased levels of these products may depict inherent oxidative routs of $\mathrm{CCl}_{4}$ on membrane-bound lipids which might have disrupted membrane fluidity and orientation. The attenuation of $\mathrm{CCl}_{4}$-mediated increase in the MDA level by EOAE is suggestive of considerable level of protection on the membrane lipids. This could be adduced to ability of the extract to enhance detoxification of reactive metabolites, which could have initiated and promoted peroxidation of polyunsaturated lipids of the hepatocyte membrane. Our submissions are in conformity with previous reports (Gini and Muraleedhara, 2010; Ajani et al., 2014) that administration of plant extracts resulted in improved antioxidant status in xenobiotic-mediated hepatic injury in rats.

Accompanying these biochemical changes are histological changes of the hepatocytes which may also give clues on how therapeutically potent an agent is against hepatic injury. 
The apparently annulled degenerative threats posed by $\mathrm{CCl}_{4}$ on the architectural features of hepatocytes in the extract-administered rats possibly suggest that EOAE significantly protected and stabilized the overall histoarchitectural integrity of the liver. It is noteworthy that, the hepatocyte regeneration progress and architectural organization of some of the hepatocytes of the EOAE-treated rats was almost normalized with increasing number of viable cells as evidently shown by hepatocyte scores. The effects noticed compared favourably with vitamin $\mathrm{C}$ and is consistent with the results of the biochemical assays in this study. Our report agrees with the submissions of Fukao et al. (2004) and Adeneye et al. (2015), where recovery towards normalization of serum enzymes and liver histological architecture caused by $\mathrm{CCl}_{4}$ in rats was attributed to treatment with plant extracts.

Overall, the elicited antioxidant and hepatoprotective properties of EOAE in this study could be attributed to its constituents as revealed from the GCMS data. Apart from the preventive and chain-breaking antioxidant properties of these compounds, significant hepatoprotective effects of triterpenoic acid, 1,8-cineole, $\alpha$-terpene and quercetin have been reported (Santos, 2001; Jian-Guo et al., 2016; Karacaa et al., 2016; Selvaraj et al., 2016). Studies have also lent credence to the capabilities of ursolic acid, thymol, eucalyptol and procyanidins to enhance regeneration of hepatocytes following exposure to chemical hepatotoxins (Janbaz et al., 2003; Ciftci et al., 2011; Gabriel et al., 2016; Min et al., 2016).

In view of the foregoing, a tentative mechanism of antioxidative and hepatoprotective potentials of EOAE may be idealized. This could be proposed to involve induction and optimization of chain-breaking (SOD, GRx) and preventive (CAT, GPx) antioxidants that conversely improved the cellular GSH level, scavenged $\mathrm{CCl}_{3} *$ and $\mathrm{CCl}_{3} \mathrm{OO}$, and significantly inhibited oxidative radicals. This eventually modulated membrane fluidity and protected the membrane of the liver cells.

\section{CONCLUSION}

This study suggests that EOAE significantly elicited hepatoprotective property in $\mathrm{CCl}_{4}$-mediated hepatic injury in rats. This property may be attributed to its antioxidant potential as evidently shown by inducing reactive metabolites detoxifying enzymes and scavenging free radicals generated by $\mathrm{CCl}_{4}$. These findings enrich biochemical and histological data supporting the use of the extract in the management and treatment of druginduced hepatic disorders.

\section{ACKNOWLEDGMENT}

Many thanks to the students (2015/2016 academic session) of Kwara State University, Malete, Nigeria, who participated and assisted in seeing this work to completion.

\section{Financial support and sponsorship: Nil.}

Conflict of Interests: There are no conflicts of interest.

\section{REFERENCES}

Adekeye AO, Akintayo CO, Adewale O, Sabiu S, Ogundele OM. Carbon tetrachloride (CCl4)-induced hepatic damage in experimental sprague dawley rats: Antioxidant potential of Xylopia aethiopica. J Phytopharmacol, 2014; 3: 118-123.

Adeneye AA, Olufunsho A, Sheriff AA, Adokiye SB. Modulatory potentials of the aqueous stem bark extract of Mangifera indica on carbon tetrachloride-induced hepatotoxicity in rats. J Trad Complement Med, 2015; 5:106-115.

Aebi H. Catalase in vitro. Meth Enzymol, 1984; 105:121-126.

Ajani EO, Sabiu S, Bamisaye FA, Adenigba BV, Awomoyi DD, Adeyanju MM. Hepatoprotective and antioxidative effect of ethanolic leaf extract of Langenaria breviflora (bitter gourd) on indomethacin-ulcerated rats. J Pharm Biological Sci, 2014; 9: 61-68.

Balogun FO, Ashafa AOT. Antioxidant, hepatoprotective and ameliorative potentials of aqueous leaf extract of Gazania krebsiana (Less.) against carbon tetrachloride $\left(\mathrm{CCl}_{4}\right)$-induced liver injury in Wistar rats. Transac Roy Soc South Afr, 2016; 145-156.

Barry KM, Janos DP, Nichols S, Bowman DMJS. Eucalyptus obliqua seedling growth in organic vs. mineral soil horizons. Frontiers Plant Sci, 2015; 6: 97.

Basu S. Carbon tetrachloride-induced lipid peroxidation: eicosanoid formation and their regulation by antioxidant nutrients. Toxicol, 2003; 189:113-127.

Cesaratto L, Vascotto C, Calligaris S, Tell G. The importance of redox state in liver damage. Ann Hepatol, 2004; 3: 86-92.

Ciftci O, Ozdemir I, Tanyildizi S, Yildiz S, Oguzturk H. Antioxidative effects of curcumin, $\beta$-myrcene and 1, 8-cineole against 2, 3, 7, 8-tetrachlorodibenzo-p-dioxin-induced oxidative stress in rats liver. Toxicol Ind Health, 2011; 27: 447-53

Drury RAB, Wallington EA. Carleton's Histological Techniques $5^{\text {th }}$ edition. Oxford University Press, 1980; 36-148.

Ellman GL. Tissue sulfhydryl groups. Arch Biochem Biophys, 1959; 82: 70-77.

Fukao T, Hosono T, Misawa S, Seki T, Ariga T. The effect of allyl sulfides on the induction of phase II detoxification enzymes and liver injury by carbon tetrachloride. Food Chem Toxicol, 2004; 42: 743-749.

Gabriel AGA, Georgina SA, Mariana M, Adelina J. Hepatoprotective properties of oleanolic and ursolic acids in antitubercular drug-induced liver damage. Asian Pac J Trop Med, 2016; 9: 644-651.

Gini CK, Muraleedhara GK. Hepatoprotective effect of Spirulina lonar on paracetamol induced liver damage in rats. Asian J Exp Biol Sci, 2010; 1: 614-623.

Guo-Cai Y, Jie LV, Hui H, Wen H, Ying H. Hepatoprotective effects of corn peptides against carbon tetrachloride-induced liver injury in mice. J Food Biochem, 2012; 36: 458-464.

Hissin PJ, Hilf R. A fluorometric method for determination of oxidized and reduced glutathione in tissues. Anal Biochem, 1976; 74: $214-$ 226.

Jaeschke H, Knight TR, Bajt ML. The role of oxidant stress and reactive nitrogen species in acetaminophen hepatotoxicity. Toxicol Lett, 2003; 144: 279-288.

Janbaz KH, Saeed SA, Gilani AH. Hepatoprotective effect of thymol on chemical-induced hepatotoxicity in rodents. Pakistan J Biol Sci, 2003; 6: 448-451

Jian-Guo W, Yong-Jun K, Yan-Bin W, Jun Y, Ti-Qiang C, JinZhong W. Hepatoprotective effect of ganoderma triterpenoids against oxidative damage induced by tert-butyl hydroperoxide in human hepatic HepG2 cells, Pharm Biol, 2016; 54: 919-929

Karacaa M, İlhanb F, Altana H, Himc A, Tütüncüa M, Özbek $\mathrm{H}$. Evaluation of hepatoprotective activity of Bergamot orange in rats. Eastern J Med, 2005; 10: 1 - 4

Lu KL, Tsai CC, Ho LK, Lin CC, Chang YS. Preventive effect of the Taiwan folk medicine Ixeris laevigata var. oldhami on a-naphthylisothiocyanate and carbon tetrachloride-induced acute liver injury in rats. Phytother Res, 2002; 16: 45-50. 
Mahmud ZA, Bachar SC, Qais N. Antioxidant and hepatoprotective activities of ethanolic extracts of leaves of Premna esculenta roxb. against carbon tetrachloride-induced liver damage in rats. J Young Pharm, 2012; 4: 228-234.

Marklund S, Marklund G. Involvement of superoxide anion radical in the autooxidation of pyrogallol and a convenient assay for superoxide dismutase. Eur J Biochem, 1974; 47: 469-474.

Min JB, Van-Long T, Se-Yeon K, Xuan NGN, Pajaree I, Mira J, Jin YS, Woo-Sik J. Antioxidant and hepatoprotective effects of procyanidins from wild grape (Vitis amurensis) seeds in ethanol-induced cells and rats. Int $\mathrm{J} \mathrm{Mol} \mathrm{Sci,} \mathrm{2016;} \mathrm{17:} 758$.

National Research Council (NRC). Guide for the Care and Use of Laboratory Animals. 8th Ed., in: Guide for the Care and Use of Laboratory Animals. National Research Council, 2011; 118.

Oloyede OB, Sunmonu TO. Potassium bromate content of selected bread samples in Ilorin, Central Nigeria and its effect on some enzymes of rat liver and kidney. Food Chem Toxicol, 2009; 47: 20672070.

Rajib A, Moniru KI, Musaddik A, Haque A. Hepatoprotective activity of methanol extract of some medicinal plants against carbon tetrachloride induced hepatotoxicity in albino rats. Global J Pharmacol, 2009; 3: 116-122.

Reilly CA, Aust SD. Measurement of lipid peroxidation. Curr Protoc Toxicol, 2001; 2: 2-4.

Risal P, Hwang PH, Yun BS, Yi H-K, Cho BH, Jang KY, Jeong YJ. Hispidin analogue davallialactone attenuates carbon tetrachlorideinduced hepatotoxicity in mice, J Nat Prod, 2012; 75: 1683-1689.

Rotruck JT, Pope AL, Ganther HE. Selenium: Biochemical role as a component of glutathione peroxidase. Sci, 1973; 179: 588-590.

Sabiu S, O’Neill FH, Ashafa AOT. Zea mays, Stigma maydis prevents and extenuates acetaminophen-perturbed oxidative onslaughts in rat hepatocytes, Pharm Biol, 2016. http://dx.doI.org/10.1080/13880209.20161178307

Sabiu S, Sunmonu TO, Ajani EO, Ajiboye OT. Combined administration of silymarin and vitamin $\mathrm{C}$ stalls acetaminophen-mediated hepatic oxidative insults in Wistar rats. Braz J Pharmacog, 2015; 25: 2934.

Sabiu S, Wudil AM, Sunmonu TO. Combined administration of Telfaira occidentalis and Vernonia amygdalina leaf powders ameliorates Garlic-induced hepatotoxicity in Wistar rats. Pharmacologia, 2014; 5: 191-198.
Sabiu S, Ashafa AOT. Membrane stabilization and kinetics of carbohydrate metabolizing enzymes ( $\alpha$-amylase and $\alpha$-glucosidase) inhibitory potentials of Eucalyptus obliqua L. Her. (Myrtaceae) Blakely ethanolic leaf extract: An in vitro assessment. South Afr J Bot, 2016; 105: 264-269.

Santos FA. 1, 8-cineole protects against liver failure in an invivo murine model of endotoxemic shock. J Pharm Pharmacol, 2001;53: 505-11

Selvaraj M, Michał T, Krystyna S, Luca R, Maria D, Seyed FN, Seyed MA, Seyed MN. Hepatoprotective effect of quercetin: From chemistry to medicine. Food and Chem Tox. In press. 2016. http://dx.doi.org/10.1016/j.fct.2016.08.034

Surendra KS, Suman A, Neeru V. Hepatoprotective activity of Vitis vinifera root extract against carbon tetrachloride-induced liver damage in rats. Acta Pol Pharmaceut Drug Res, 2012; 69: 933-937.

Thabrew MI, Joice PD, Rajatissa, W. A comparative study of the efficacy of Pavettaindica and Osbeckia octanda in the treatment of liver dysfunction. Planta Medica, 1987; 53: 239-241.

Tietz NW. Clinical guide to laboratory tests. 3rd edn. W.B. Saunders, Philadelphia, USA, 1995.

Wang H, Wei W, Wang NP, Gui SY, Wu L, Sun WY, Xu SY. Melatonin ameliorates carbon tetrachloride-induced hepatic fibrogenesis in rats via inhibition of oxidative stress. Life Sci, 2005; 77: 1902-1915.

Ward FM, Daly MJ. Hepatic disease. In: Clinical pharmacy and therapeutics (Walker R. and C. Edwards Eds.). Churchill Livingstone, New York, 1999; 195-212

Weber LW, Boll M, Stampfl A. Hepatotoxicity and mechanism of action of haloalkanes: carbon tetrachloride as a toxicological model. Crit Rev Toxicol, 2003; 33: 105-136.

\section{How to cite this article:}

Sabiu S, Ajani EO, Sunmonu TO, Balogun FO, Ashafa AOT, Othman BR, Olowa KS., Mechanism of hepatoprotective potential of aqueous leaves extract of Eucalyptus obliqua (Myrtaceae) in carbon tetrachloride intoxicated Wistar rats. J App Pharm Sci, 2017; 7 (08): 183-190. 